\title{
Evaluation of environmentally-friendly crop management systems based on very early sowing dates for winter oilseed rape in France
}

\author{
Jean-François DeJouX ${ }^{a}$, Jean-Marc MEYNARD ${ }^{a *}$, Raymond REAU ${ }^{\mathrm{b}}$, Romain RocHE ${ }^{\mathrm{c}}$, Patrick SAUlaS ${ }^{\mathrm{a}}$ \\ ${ }^{a}$ Unité d'Agronomie INRA-INAPG, BP 01, 78850 Thiverval-Grignon, France \\ ${ }^{\mathrm{b}}$ CETIOM, BP 04, 78850 Thiverval-Grignon, France \\ ${ }^{\mathrm{c}}$ INRA, Unité Environnement et Grandes Cultures, BP 01, 78850 Thiverval-Grignon, France
}

(Received 7 February 2002; accepted 31 July 2003)

\begin{abstract}
We assessed new crop management systems for winter oilseed rape based on very early sowing dates, with a view to improving environmental performance without decreasing economic benefits. In a network of 36 trials conducted over 3 years in France, the new systems turned out to be more effective than current systems in terms of environmental variables: absorption of almost all the mineral $\mathrm{N}$ present in the soil in autumn, even after organic manure spreading; nitrate concentration of the percolated water below $50 \mathrm{mg} \cdot 1^{-1}$, and lower levels of molluscicide use, even in years of heavy slug infestation. The gross margin was optimised by very early sowing, which in most trials resulted in yields equal to or greater than those for crops sown at the usual date. We typed the trials, linking the difference in yield between the two crop management systems to various limiting factors (crop establishment, stem canker and nitrogen nutrition), to identify situations appropriate for the new crop management systems.
\end{abstract}

cropping systems / winter oilseed rape / sowing dates / nitrate leaching / nitrogen management / integrated pest management

Résumé - Évaluation en France d'itinéraires techniques du colza d'hiver favorables à l'environnement, basés sur des semis très précoces. Notre objectif est l'évaluation de nouveaux itinéraires techniques du colza basés sur des semis très précoces, afin d'améliorer le bilan environnemental de cette culture sans affecter son bilan économique. Sur un réseau de 36 essais pendant 3 années en France, les nouveaux itinéraires techniques se sont avérés plus efficaces que les itinéraires techniques actuellement recommandés au niveau des performances environnementales : absorption, au cours de l'automne, de la quasi totalité de l'azote minéral du sol même après épandage d'effluent organique ; teneur en nitrate de l'eau percolée inférieure à $50 \mathrm{mg} \cdot l^{-1}$; réduction de l'emploi de molluscicides, même en année de forte infestation de limaces. En terme de marge brute, les résultats moyens furent favorables aux semis très précoces qui permirent, sur la majorité des essais, un rendement supérieur ou égal à celui des semis à date normale. Une typologie des essais reliant la différence de rendement entre les deux itinéraires techniques à différents facteurs limitants (implantation de la culture, phoma, nutrition azotée), est utilisée afin de définir le domaine de validité des nouveaux itinéraires techniques.

itinéraires techniques / colza d'hiver / dates de semis / lixiviation du nitrate / gestion de l'azote / protection intégrée

\section{INTRODUCTION}

The choice of sowing date for a crop involves a complex set of factors that affect the entire annual sequence of agronomic operations. Fleury [11] identified the three objectives most usually taken into account when choosing a sowing date: (i) ensuring that high-quality germination and emergence are possible; (ii) optimising the weight and number of the harvested plant parts, and (iii) timing the cycle so as to limit the incidence of periods unfavourable to the crop (various stresses, parasites, frost, drought, etc.). For winter oilseed rape in France, these objectives correspond to: (i) early uniform emergence, which can be difficult to achieve because the crop is often sown in dry conditions [28]; (ii) ensuring adequate growth to protect against early winter frosts [21], and (iii) ensuring that the leaf area index and taproot reserves after winter are sufficient to allow the crop to start growing quickly in spring [20]. Based on these objectives, it is currently recommended that winter oilseed rape crops be sown at the end of August (North of France) or the beginning of September (South) [5].

The sowing date is thus chosen so as to optimise production, without considering environmental side effects. It is usually possible to bring forward the sowing date of winter rape, as the preceding crop is in most cases a cereal, harvested one or two months before current oilseed rape sowing dates. Such early sowing is thought to have several environmental advantages.

Communicated by Gérard Guyot (Avignon, France)

* Corresponding author: meynard@grignon.inra.fr 
Rape sown very early has a longer growth period before winter than rape sown at the normal date. It would therefore be expected to have a better potential for growth and nitrogen absorption [36]. Rape sown very early could therefore be used as a highly efficient nitrate trap. According to Reau et al. [29], the nitrogen contained in the rape stand in late winter can be deducted from spring fertiliser applications: very early sowing would thus be a way of reducing nitrogen fertiliser applications. In addition, the high growth potential of winter oilseed rape sown very early could render this crop highly competitive against weeds [19].

According to the epidemiological data available, very early sowing may well reduce the development of stem canker (Leptosphaeria maculans Desm.) by separating the period in which the risk of contamination by this fungus is high from that in which the plant is susceptible [27]. Similarly, slugs are unlikely to do much damage if the crop is sown very early, given the dry weather conditions after emergence. In addition, when conditions become more favourable for slugs in September or October, rape plants that emerged one or two months earlier would have a high enough leaf area index not to be susceptible to slug damage [16]. If these hypotheses are sound, then early sowing of winter oilseed rape would have both environmental advantages and the economic advantage of higher yields with less inputs (slug pellets, pesticides and nitrogen fertiliser).

However, there are certain risks associated with bringing forward the sowing date: very early sowing may expose the crop to higher risks of frost damage [20] (damage to leaves and plants in winter and to flowers in spring), poor emergence and insect damage in summer [37]. Any of these factors may result in low or irregular yields, or may increase the use of crop protection chemicals.

In this study, we aimed to assess new crop management systems (i.e. schedules for agronomic operations) for oilseed rape production, with a view to improving environmental performance without decreasing economic benefits. This assessment involved a network of experimental trials in a wide range of conditions (soil type, climate and region), designed to generate not only mean results or results under ideal conditions, but also to identify the risks these new crop management systems entail, and to establish which geographical areas are most suitable for very early rape sowing.

\section{MATERIALS AND METHODS}

\subsection{Experimental design}

On-farm experiments were conducted over three years and in three regions of contrasting climatic conditions in France. An "autumn" network including 36 trials was followed through to the end of winter. A "spring" network, with 26 of these 36 trials, continued right through to harvest (Tab. I and Fig. 1). We investigated the nitrate-trapping capacities of rape in nitrogen-rich soil by applying organic manure (total $\mathrm{N}$ of 80 to $\left.200 \mathrm{~kg} \cdot \mathrm{ha}^{-1}\right)$ in four of the trials and mineral nitrogen fertiliser $\left(100 \mathrm{~kg} \cdot \mathrm{ha}^{-1}\right)$ in three trials, in July, before sowing (simulation of low fertiliser recovery by the previous crop). Seven of the trials were run on shallow rendzinas, the rest on deep loams, with a potential rooting depth of about $90 \mathrm{~cm}$.

Each trial had an identification number, consisting of the sowing year $(95,96$ or 97$)$ followed by a serial number (e.g. 95-1, 97-13). The experimental crop management systems were used, without replicates, on large plots of farmland (roughly $1000 \mathrm{~m}^{2}$ per experimental treatment). For this reason, we carried out trials only after verification of the uniformity of the soil type over the whole plot (same layers on the same depth).

\subsection{Crop management systems and decision rules}

The crop management systems were implemented by the farmers, but the dates, rates of active ingredients and implements were set by the team of researchers, based on a set of decision rules as recommended by Meynard et al. [24] and Reau et al. [30]. According to these authors a decision rule links the decision to the general objectives of the crop management system, the "rule" itself being expressed in terms of "if (condition)... then (decision)". If the objectives of the crop management system are attained with the set of decision rules in a representative network of trials, then the set of rules is a valid basis for application of the crop management system to areas with different environmental conditions and for the dissemination of this system in agriculture [24].

All trials included two experimental treatments applying different crop management systems: VES for very early sowing and NS for normal sowing. We used the same rape variety, Goëland, in all trials. The only rules that differed between the two treatments were those governing sowing dates and the use of pesticides active against slugs (Tab. II):

- Sowing. For NS, we followed the methods recommended by CETIOM [4]; for VES, we sowed one month earlier, at the same density.

- Slug protection. For VES, we accepted the risk of having to re-sow at the normal date if the crop was destroyed by slugs; for this reason, we used only curative treatments if damage to rape plantlets was observed.

The decision rules for the other techniques were similar for the two crop management systems; they were based on CETIOM recommendations [4] and are detailed in Table II. As the trials were conducted under different environmental conditions, applying the same rules did not lead to the same technical decisions in all trials. In a given trial, the difference in sowing date led to differences in $\mathrm{N}$ uptake in autumn and pest pressure between the two crop management systems. Therefore, $\mathrm{N}$ fertiliser application rates and the number and dates of insecticide applications differed, although the decision rules for these techniques were the same (Tab. II).

Pre-emergence herbicides were systematically applied. Rates of nitrogen fertiliser application in spring were adjusted to the needs of the stand (in accordance with the target yield) and calculated by the balance sheet method adapted for rape crops [29]. Target yields were the same for both crop management systems and were determined for each trial according to the potential of the plot, based on the yield achieved in seven years out of ten. If there was too little growth in the autumn (less 
Table I. Regional and temporal distribution of the experiments, soil type and preceding crop.

\begin{tabular}{|c|c|c|c|c|c|c|}
\hline $\begin{array}{l}\text { Experiment } \\
\text { number }\end{array}$ & Year & Region & $\mathrm{N}$ application before sowing & $\begin{array}{l}\text { Soil type (FAO } \\
\text { classification) }\end{array}$ & Preceding crop & $\begin{array}{c}\text { Spring } \\
\text { monitoring }\end{array}$ \\
\hline 95.1 & $1995 / 96$ & East & - & Orthic rendzina & Spring barley & Yes \\
\hline 95.2 & $1995 / 96$ & Centre-West & - & Gleyic luvisol & Winter wheat & NO \\
\hline 95.3 & $1995 / 96$ & Centre-West & Cattle slurry $\left(40 \mathrm{Mg} / \mathrm{ha}^{-1}-156 \mathrm{kgN} \cdot \mathrm{ha}^{-1}\right)$ & Gleyic luvisol & Winter wheat & Yes \\
\hline 95.4 & $1995 / 96$ & Centre-West & - & Albic luvisol & Triticale & NO \\
\hline 95.5 & $1995 / 96$ & Centre-West & - & Albic luvisol & Winter wheat & NO \\
\hline 95.6 & $1995 / 96$ & South & - & Orthic luvisol & Winter wheat & NO \\
\hline 95.7 & $1995 / 96$ & South & - & Orthic luvisol & Spring pea & NO \\
\hline 96.1 & $1996 / 97$ & East & - & Orthic rendzina & Winter wheat & Yes \\
\hline 96.2 & 1996/97 & East & - & Orthic rendzina & Spring barley & Yes \\
\hline 96.3 & $1996 / 97$ & East & - & Orthic rendzina & Winter barley & Yes \\
\hline 96.4 & 1996/97 & East & - & Orthic rendzina & Winter barley & NO \\
\hline 96.5 & $1996 / 97$ & Centre-West & - & Albic luvisol & Winter wheat & NO \\
\hline 96.6 & $1996 / 97$ & Centre-West & Turkey slurry $\left(15 \mathrm{Mg} / \mathrm{ha}^{-1}-216 \mathrm{kgN} \cdot \mathrm{ha}^{-1}\right)$ & Albic luvisol & Winter wheat & Yes \\
\hline 96.7 & 1996/97 & Centre-West & - & Orthic luvisol & Winter wheat & Yes \\
\hline 96.8 & $1996 / 97$ & Centre-West & - & Gleyic luvisol & Winter barley & Yes \\
\hline 96.9 & $1996 / 97$ & Centre-West & Urban sludge $\left(20 \mathrm{Mg} / \mathrm{ha}^{-1}-124 \mathrm{kgN} \cdot \mathrm{ha}^{-1}\right)$ & Gleyic luvisol & Winter barley & Yes \\
\hline 96.10 & 1996/97 & Centre-West & - & Orthic rendzina & Winter wheat & NO \\
\hline 96.11 & 1996/97 & Centre-West & - & Albic luvisol & Winter wheat & Yes \\
\hline 96.12 & $1996 / 97$ & South & - & Orthic luvisol & Winter wheat & NO \\
\hline 96.13 & $1996 / 97$ & South & - & Orthic luvisol & Spring pea & Yes \\
\hline 96.14 & $1996 / 97$ & South & - & Orthic luvisol & Spring barley & Yes \\
\hline 96.15 & $1996 / 97$ & South & Chicken slurry $\left(9 \mathrm{Mg} / \mathrm{ha}^{-1}-233 \mathrm{kgN} \cdot \mathrm{ha}^{-1}\right)$ & Orthic luvisol & Spring barley & Yes \\
\hline 96.16 & $1996 / 97$ & South & - & Orthic luvisol & Winter wheat & NO \\
\hline 97.1 & $1997 / 98$ & East & - & Orthic rendzina & Winter barley & Yes \\
\hline 97.2 & $1997 / 98$ & East & - & Orthic rendzina & Spring barley & Yes \\
\hline 97.3 & $1997 / 98$ & East & - & Orthic luvisol & Winter wheat & Yes \\
\hline 97.4 & $1997 / 98$ & Centre-West & - & Orthic rendzina & Winter wheat & Yes \\
\hline 97.5 & $1997 / 98$ & Centre-West & $\begin{array}{l}\text { Ammonium nitrate } \\
\left(100 \mathrm{kgN} \cdot \mathrm{ha}^{-1}\right)\end{array}$ & Cambic rendzina & Winter wheat & Yes \\
\hline 97.6 & 1997/98 & Centre-West & - & Orthic luvisol & Winter wheat & Yes \\
\hline 97.7 & $1997 / 98$ & Centre-West & Ammonium nitrate & Orthic luvisol & Winter wheat & Yes \\
\hline & & & $\left(100 \mathrm{kgN} \cdot \mathrm{ha}^{-1}\right)$ & & & \\
\hline 97.8 & $1997 / 98$ & Centre-West & - & Albic luvisol & Spring barley & Yes \\
\hline 97.9 & $1997 / 98$ & South & - & Orthic luvisol & Winter wheat & Yes \\
\hline 97.10 & $1997 / 98$ & South & - & Orthic luvisol & Spring pea & Yes \\
\hline 97.11 & $1997 / 98$ & South & - & Orthic luvisol & Winter wheat & Yes \\
\hline 97.12 & $1997 / 98$ & South & - & Albic luvisol & Winter wheat & Yes \\
\hline 97.13 & $1997 / 98$ & South & Ammonium nitrate $\left(100 \mathrm{kgN} \cdot \mathrm{ha}^{-1}\right)$ & Albic luvisol & Winter wheat & Yes \\
\hline
\end{tabular}

than $10 \mathrm{~kg} \cdot \mathrm{ha}^{-1}$ of stored nitrogen in the aerial parts in late winter), target yields could be adjusted downwards, for either sowing date. We estimated $\mathrm{N}$ supply in late winter (when the nitrogen balance sheet was started) by measuring the nitrogen content of the plants (see method in Sect. 2.3) and the mineral nitrogen content of the soil.

For two cropping techniques (soil tillage and post-emergence weeding), we were unable, based on our scientific knowledge and technical know-how, to formulate rules that could be applied nationwide. In each trial, decisions were taken jointly by the farmer and the research team, so as to ensure a high level of crop emergence (tillage) and to limit the growth and number of weeds that might produce seeds or reduce oilseed rape yield (post-emergence weeding). The soil was first tilled immedi- ately after harvest of the previous crop to bury stubble and straw and to allow the emergence of cereal volunteers, except in 7 cases of direct drilling. The type of implement used depended on soil type, soil moisture and the equipment available: plough (deep work) or disk harrow (shallow tillage). After this initial tillage the soil was turned by one or two shallow tillage operations (disk harrow or cultivator). For VES, sowing was carried out soon afterwards; for NS, the soil was not re-tilled before the day on which the crop was sown, to encourage weed emergence so that the weeds could then be destroyed during seedbed preparation. The weeds that emerged were preferentially destroyed by soil tillage or, in 3 cases, by a non-selective herbicide (glyphosate). The decision to apply post-emergence herbicides depended on weed type, weed density and the development stages of both the weeds and the crop. 


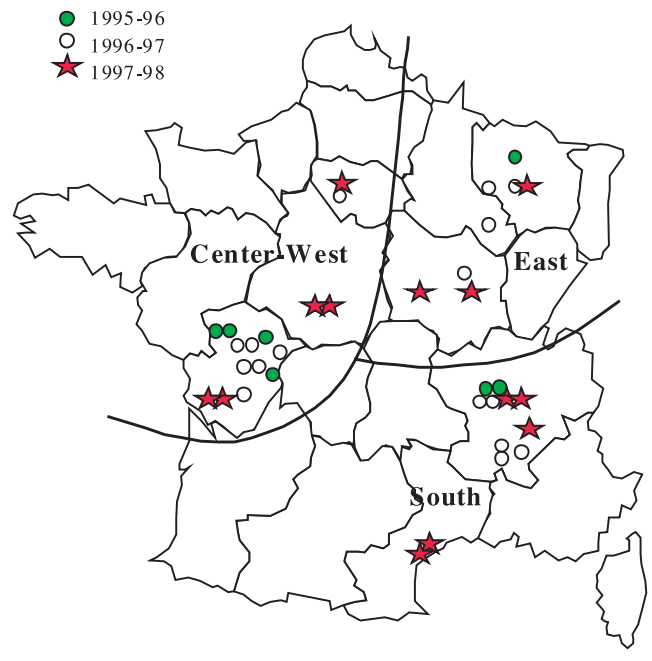

Figure 1. Location of the 36 trials, according to the year of experimentation and to the region of France (East, South and CenterWest).

\subsection{Measurements and observations}

Plants. Plant samples were taken in three periods: (i) in early winter before the period of strong winter drainage (early November in the east to late November in the south); (ii) in late winter, when active rape growth begins again (January 20 in the south to February 20 in the east), and (iii) at the G4 stage (first pods with their grains at definitive size), regarded as the end of spring nitrogen absorption (June 1 in the south to June 15 in the east). Samples were taken from six micro-plots of $0.5 \mathrm{~m}^{2}$ in early winter and late winter and from six micro-plots of $1 \mathrm{~m}^{2}$ at the $\mathrm{G} 4$ stage. The plants were counted and the roots separated from the aerial parts after washing. Dry matter content (following 48 hours of drying at $80{ }^{\circ} \mathrm{C}$ ) and total nitrogen content (Dumas method) were determined for each micro-plot sample. For three micro-plots, a sample of 12 plants was used to count the number of leaf scars, green leaves and senescent leaves per plant. For each experimental treatment, lodging was recorded at the G4 stage, according to the CETIOM ranking of $1-9$, with 9 corresponding to the most severe lodging [3].

Table II. Decision rules for cropping techniques.

\begin{tabular}{|c|c|c|}
\hline Cropping techniques & Function & Rule \\
\hline \multicolumn{3}{|c|}{ Decision rules different for the two crop management systems } \\
\hline Sowing date for NS & $\begin{array}{l}\text { Reaching at least the 6-leaf stage } \\
\text { in early winter }\end{array}$ & $\begin{array}{c}\text { South }=\text { about September } 5(*) \\
\text { Centre-West }=\text { about September } 1(*) \\
\text { East }=\text { about August } 25(*)\end{array}$ \\
\hline Sowing date for VES & $\begin{array}{l}\text { High growth and } \mathrm{N} \text { uptake } \\
\text { before winter }\end{array}$ & 1 month before the NS \\
\hline Molluscicides for NS & $\begin{array}{l}\text { Assuring a maximal protection } \\
\text { at plant establishment }\end{array}$ & $\begin{array}{l}\text { Preventive applications if soil or weather are favourable to slug activity; } \\
\text { curative application only if injury is observed }(*)\end{array}$ \\
\hline Molluscicides for VES & $\begin{array}{l}\text { Limiting the use of } \\
\text { molluscicides }\end{array}$ & Curative applications only if injury is observed $(*)$ \\
\hline \multicolumn{3}{|c|}{ Decision rules identical for the two crop management systems } \\
\hline Sowing rate & $\begin{array}{l}\text { Objective of plant density after } \\
\text { emergence: } 50 \text { plants per } \mathrm{m}^{2}(*)\end{array}$ & $\begin{array}{l}\text { If seedbed is well prepared: sow at } 60 \text { seeds per } \mathrm{m}^{2} \\
\text { If not, sow at } 80 \text { seeds per } \mathrm{m}^{2}\end{array}$ \\
\hline $\begin{array}{l}\text { Fungicide, } \mathrm{N} \text { fertiliser } \\
\text { and growth regulator } \\
\text { applications in autumn }\end{array}$ & & No application $(*)$ \\
\hline Insecticides & $\begin{array}{l}\text { Protection based on a risk } \\
\text { assessment }(*)\end{array}$ & $\begin{array}{l}\text { If field thresholds are available, apply insecticides according to field insect trapping } \\
\text { (cabbage stem flea beetle and stem weevil) or to plot-by-plot observations } \\
\text { (greenfly on plants) }(*) .\end{array}$ \\
\hline Spring nitrogen fertiliser & Avoiding N deficiency & $\begin{array}{l}\text { If not, follow recommendations from regional observation network (terminal bud weevil) } \\
\text { Apply the balance sheet method [39]. If spring fertiliser rate is above } 80 \mathrm{~kg} \cdot \mathrm{ha}^{-1} \text {, } \\
\text { application rate is divided into two equivalent rates, applied after winter } \\
\text { when active regrowth of plant begins }(*)\end{array}$ \\
\hline Spring sulphur fertiliser & Avoiding S deficiency & $\begin{array}{l}\text { If winter is wet or the soil is shallow, application is obligatory, and is combined } \\
\text { with the second } \mathrm{N} \text { application }(*) \text {. } \\
\text { If not, no application }\end{array}$ \\
\hline Pre-emergence weeding & $\begin{array}{l}\text { Limiting emergence of weeds } \\
\text { that can produce seeds or reduce } \\
\text { rape yield }\end{array}$ & $\begin{array}{l}\text { Herbicide application is systematic. Choice and amount of active ingredient according to } \\
\text { prior knowledge of weed infestations of the plots: weed species and soil seed bank }\end{array}$ \\
\hline Spring fungicide & $\begin{array}{l}\text { Limiting diseases that can } \\
\text { reduce rape yield }\end{array}$ & $\begin{array}{l}\text { Protection based on climatic risk assessment and on plot observations }(*) \text {. } \\
\text { Application against Sclerotinia stem rot at early flowering of rapeseed is obligatory }\end{array}$ \\
\hline Spring growth regulator & & No application; the variety Goeland is not sensitive to lodging $(*)$ \\
\hline Tillage & & See text \\
\hline Post-emergence weeding & & See text \\
\hline
\end{tabular}

* According to CETIOM regional recommendations [4]. 
Amount of mineral nitrogen in the soil. On the same dates as the plant samples were taken, two series of three soil cores were taken per experimental treatment, from two or three soil layers $(0-30 \mathrm{~cm}, 30-60 \mathrm{~cm}$ and (in deep soils only) $60-90 \mathrm{~cm}$ ). Mineral nitrogen $\left(\mathrm{NO}_{3}{ }^{-}\right.$and $\left.\mathrm{NH}_{4}{ }^{+}\right)$was determined by colorimetry, for each layer of each series, after extraction in a solution of $\mathrm{KCl}(100 \mathrm{ml} 1 \mathrm{M} \mathrm{KCl}$ per $100 \mathrm{~g}$ fresh soil, shaken for 30 minutes). Mineral nitrogen in late winter was measured only in those trials in which there was more than $30 \mathrm{~kg} \cdot \mathrm{ha}^{-1}$ of mineral nitrogen in the soil in one of the treatments in early winter.

We used the CERES-Rape model [13] to calculate, by simulation, the amounts of nitrogen leached over winter in each trial. The simulations were carried out between "early winter" and "late winter" observation dates, initialising the model with the water and nitrogen contents of the various soil layers measured in early winter. We used the soil water transfer functions of the CERES-Rape model for specific water retention levels (wilting point LL and field capacity DUL) and values given by Driessen [10] for Ksat (hydraulic conductivity at saturation, $\mathrm{cm} \cdot \mathrm{day}^{-1}$ ), A (transmission zone permeability, $\mathrm{cm} \cdot \mathrm{day}^{-1}$ ), and gamma (coefficient of the retention curve, $\mathrm{cm}^{-2}$ ).

The crop was harvested with a combine harvester, and the yield was estimated from 3 samples of $300 \mathrm{~m}^{2}$ each. Proteins, lipids, impurities, moisture contents and weight per grain were determined on a subsample of approximately $1 \mathrm{~kg}$; the number of grains per $\mathrm{m}^{2}$ was calculated from the yield and weight per grain [3].

Diseases and pests. Crop damage was estimated on samples taken from 36 plants randomly chosen in early winter and at the G4 stage. Each sample was scored using the CETIOM [3] ranking of 1-9, with 9 corresponding to the most severe damage. Stem canker damage was estimated at the G4 stage, with scores allocated according to the degree of collar rot, from 0 (absence of damage) to 6 (collar cut through) [3].

Development stage. The emergence date was taken to be the date on which more than 10 plantlets, on average, were visible per $\mathrm{m}^{2}$, observed on 6 plots of $1 \mathrm{~m}^{2}$. The start of flowering (at least 1 flower per plant) and the end of flowering (no flowers left on the plant) were taken to be the dates on which $50 \%$ of a sample of 50 plants in a treatment had reached the stage concerned.

Soil characteristics and root establishment. A soil sample from the uppermost $30 \mathrm{~cm}$ of the soil profile for each trial was analysed by the INRA laboratory at Arras: particle size and chemical analysis (assimilable P — using the Joret-Hébert method for calcareous soils and the Dyer method for non-calcareous soils - exchangeable $\mathrm{Mg}$ and $\mathrm{K}$, total carbon and nitrogen, $\mathrm{CaCO}_{3}, \mathrm{CEC}$ and $\mathrm{pH}$ ). Rooting depth was determined from samples taken from auger holes. Some of the NS crops (trials $95.2 ; 95.3 ; 96.5 ; 96.6 ; 96.7 ; 96.8$ and 96.9) were sown in wet conditions, which may have affected soil structure and root establishment [23]. For this reason, the soil structure was observed in these trials (the day before harvest) to a depth of $80 \mathrm{~cm}$ (rooting depth), using the method described by Gautronneau and Manichon [14].

\subsection{Calculation of economic balances}

All the techniques used in each crop management system were recorded: the dates of each operation, implements used, and types and application rates of fertilisers and crop protection chemicals. The baseline data for the costs of inputs were those for 1997. The mean sale price of food-quality oilseed rape in 1996/97, 2.28 Euros per $\mathrm{Mg}$, was used in the calculations. The economic criterion used was gross margin without subsidies (Euros per hectare).

\subsection{Weather conditions for the network}

Weather conditions were very variable between locations and especially between the 3 years, but were typical of conditions that occur regularly in France.

Long dry periods between rains, lasting 2-4 weeks, occurred during or after several VES and NS sowings whereas long, cool rainy periods occurred only during or after some NS sowings. Autumn temperatures were above the seasonal mean in all three years. In contrast, considerable differences in temperature were observed between the 3 regions and the three winters: 1996 was very cold, 1995 was normal but with some late frosts and 1997 was exceptionally mild for France.

Water conditions at the end of the cropping cycle varied from year to year and from region to region. In all regions, the start of flowering (F1 stage) occurred at much the same time in all years (only 5 to 9 days later in 1995/96 than in 1996/97) and was similar for VES and NS treatments. This was not unexpected, given that oilseed rape development responds strongly to daylength [18].

\section{RESULTS}

\subsection{Tillage, sowing, emergence}

In VES plots, tillage and sowing were carried out very soon after harvest, in relatively dry conditions. The sowing date objectives (Fig. 2a) were attained in most trials. The mean time-lag between sowing dates in VES and NS plots was 29 days. In seven trials in the south and the centre-west, NS plots were sown after September 15, some 10 to 20 days after the planned sowing date. These delays were due to a lack of rain in late summer; the soil dried out after harvest, making it mechanically impossible to prepare the seedbed. It was therefore necessary to wait for rain before ploughing. In five trials (96.7; 96.8; 96.9; 97.12 and 97.13), the crop was sown when the next rains fell. However, for the other two trials (95.2 and 95.3), the first rains were followed by three weeks of heavy rain, leading to a further delay in sowing.

Late sowing during a rainy period led to soil compaction for some of these NS plots, located on gleyic luvisols. In trials 96.8 and 96.9 , we observed a highly compacted structure in a large proportion of the NS soil profile $(60 \%$ of the volume of the cultivated layers was of a continuous structure with no apparent porosity with NS, versus only $20 \%$ with VES). In late winter, the soil was saturated in only one trial (95.3), carried out on a gleyic luvisol. 

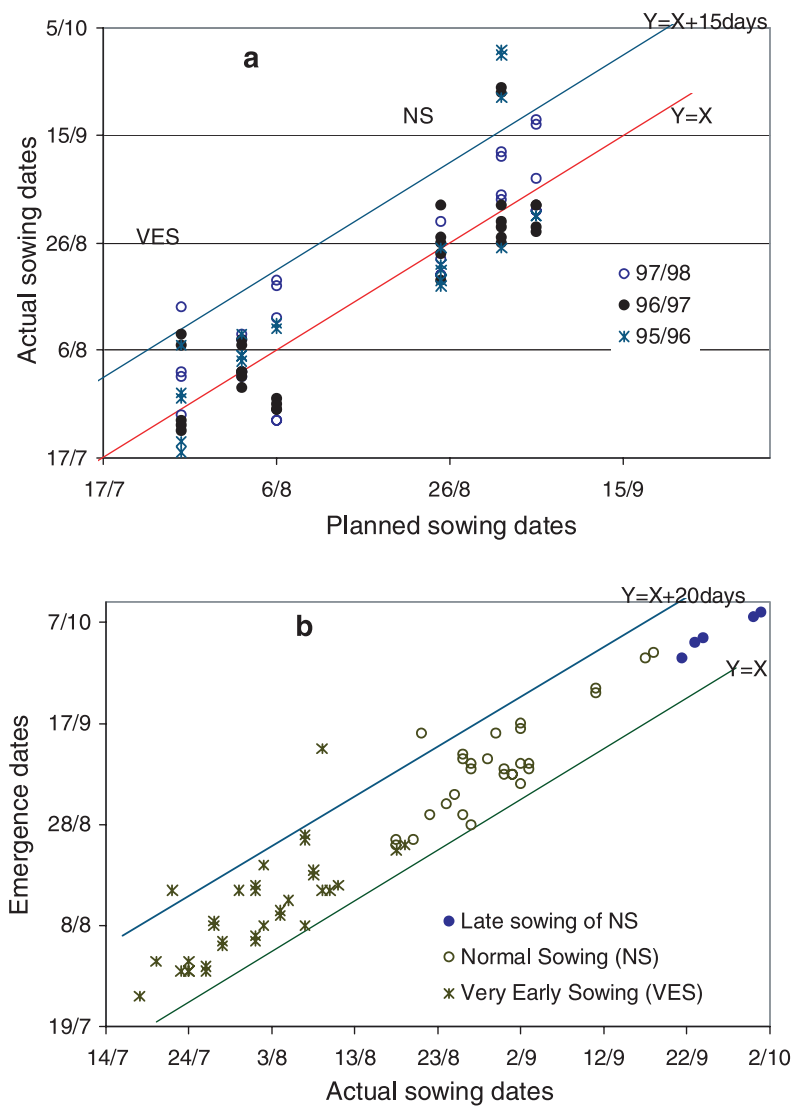

Figure 2. Actual sowing dates related to planned sowing dates (a) and emergence dates (b). The emergence dates of 6 trials were not available.

The mean duration of the period from sowing to emergence was 10 days for both the NS and VES plots, but there was some variation around this mean (Fig. 2b). This period lasted more than 20 days on one VES plot (trial 95.4) where there was no rain for a month after sowing: the VES crop emerged at the same time as the NS crop, and at the same plant density.

All VES crops were sown in soil dried out by the cereal preceding rape in the rotation and in all cases emergence occurred following rain after sowing. We observed no significant mortality of plants after emergence, although periods of two to four weeks without rain after the emergence of VES crops were recorded in numerous trials in the three regions. Emergence of NS crops also occurred after rain in all but seven trials, in which emergence began before the first rains.

The sowing density set according to the decision rule was respected in most trials (55 to 70 seeds per $\mathrm{m}^{2}$ ). However, in four trials, sowing density was increased (70 to 130 seeds per $\mathrm{m}^{2}$ ) to counter anticipated poor emergence conditions (rough seedbeds). Mean plant density in early winter was 45 plants per $\mathrm{m}^{2}$ on both VES and NS plots. Plant density varied greatly between trials and treatments, from 25 to 80 plants per $\mathrm{m}^{2}$ for NS and from 17 to 90 plants per $\mathrm{m}^{2}$ for VES, but these densities can be regarded as non-limiting for yield for both VES and $\mathrm{NS}$ alike [25]. They correlated with emergence rates $\left(\mathrm{r}^{2}=\right.$ $0.57, P=0.02, \mathrm{n}=34)$, but not with sowing densities $\left(\mathrm{r}^{2}=\right.$ 0.15 , not significant).

\subsection{Growth and nitrogen absorption; the consequences of early sowing for the mineral nitrogen store in early and late winter}

\subsubsection{Accumulation of nitrogen in the plants}

The total quantities of nitrogen accumulated in the aerial parts of the plant and in taproots in early winter are shown in Figure 3a. The number of trials is identical on either side of the bisecting line, the year of the trial having no effect. For both NS and VES, the crop accumulated more than $250 \mathrm{~kg} \mathrm{~N} \cdot \mathrm{ha}^{-1}$ in some cases, especially after the spreading of manure. Almost no accumulation was observed for only a few NS crops ( 6 NS between 1 and $5 \mathrm{~kg} \cdot \mathrm{ha}^{-1}$ ) whereas VES crops accumulated at least $20 \mathrm{~kg} \cdot \mathrm{ha}^{-1}$. Most of the crops displaying low levels of nitrogen accumulation were late-emerged NS crops.

Large numbers of leaves fell in autumn, as demonstrated by the number of leaf scars (Fig. 3b). VES plants had a mean of 3.8 more scars than NS plants (6 for VES versus 2.2 for NS), with considerable variation between trials: from 2-11 for VES and from 0-6 for NS. Neither accumulated biomass nor nitrogen deficiency could account for this variation (not illustrated). Lastly, the objective of reaching at least the 6-leaf stage by early winter was attained, except for the NS crops of a few trials in which emergence was late, and in which only 2.2 to 5.0 leaves had appeared before winter.

During the course of the winter, the levels of nitrogen accumulated in the aerial parts of the plants changed, with considerable differences between years in the pattern of change observed. During the very cold winter of the second year, onethird of the trials displayed a $50 \%$ loss of accumulated nitrogen, corresponding to a mean loss of $15 \mathrm{~kg} \cdot \mathrm{ha}^{-1}$ nitrogen. In absolute values, the decreases in accumulated nitrogen were greatest in those stands that had accumulated the most nitrogen by the onset of winter $\left(\mathrm{r}^{2}=0.64, \mathrm{n}=32, P<0.01\right)$. This resulted in a decrease in the difference between the VES and NS crops in a given trial over the course of the winter. Nitrogen losses in winter are due mainly to leaf frost (100\% of the leaves were killed in 5 trials) but also partly to the loss of individual plants (between $20 \%$ and $30 \%$ of the plants in half the trials), especially in stands with poor growth in the autumn (late-emerging NS crops, in particular 96.7; 96.8 and 96.9). However, in the first and third years, the amounts of accumulated nitrogen in the plants increased in most trials, by a mean of $9 \mathrm{~kg} \cdot \mathrm{ha}^{-1}$ in the first year and $21 \mathrm{~kg} \cdot \mathrm{ha}^{-1}$ in the third year, which had a particularly mild winter. In the third year, regardless of the crop management system used and the amount of $\mathrm{N}$ accumulated by the plants in autumn, up to $75 \mathrm{~kg} \cdot \mathrm{ha}^{-1}$ nitrogen was accumulated by the end of winter, in all regions. In many trials, the amount of nitrogen accumulated doubled over the winter.

The amount of nitrogen in rape in late winter is a major element in the calculation of nitrogen fertiliser application rates in spring [29]: the larger the amount of $\mathrm{N}$ accumulated, the lower the application rate. The two experimental treatments differed by less than $10 \mathrm{~kg} \cdot \mathrm{ha}^{-1}$ in terms of the amount of nitrogen accumulated by the plants in late winter in ten trials (Fig. 3c). The NS stand accumulated at least $10 \mathrm{~kg} \cdot \mathrm{ha}^{-1}$ more than the VES stand in ten other trials, mostly in the third year. For these 10 trials, the mean difference between the two 

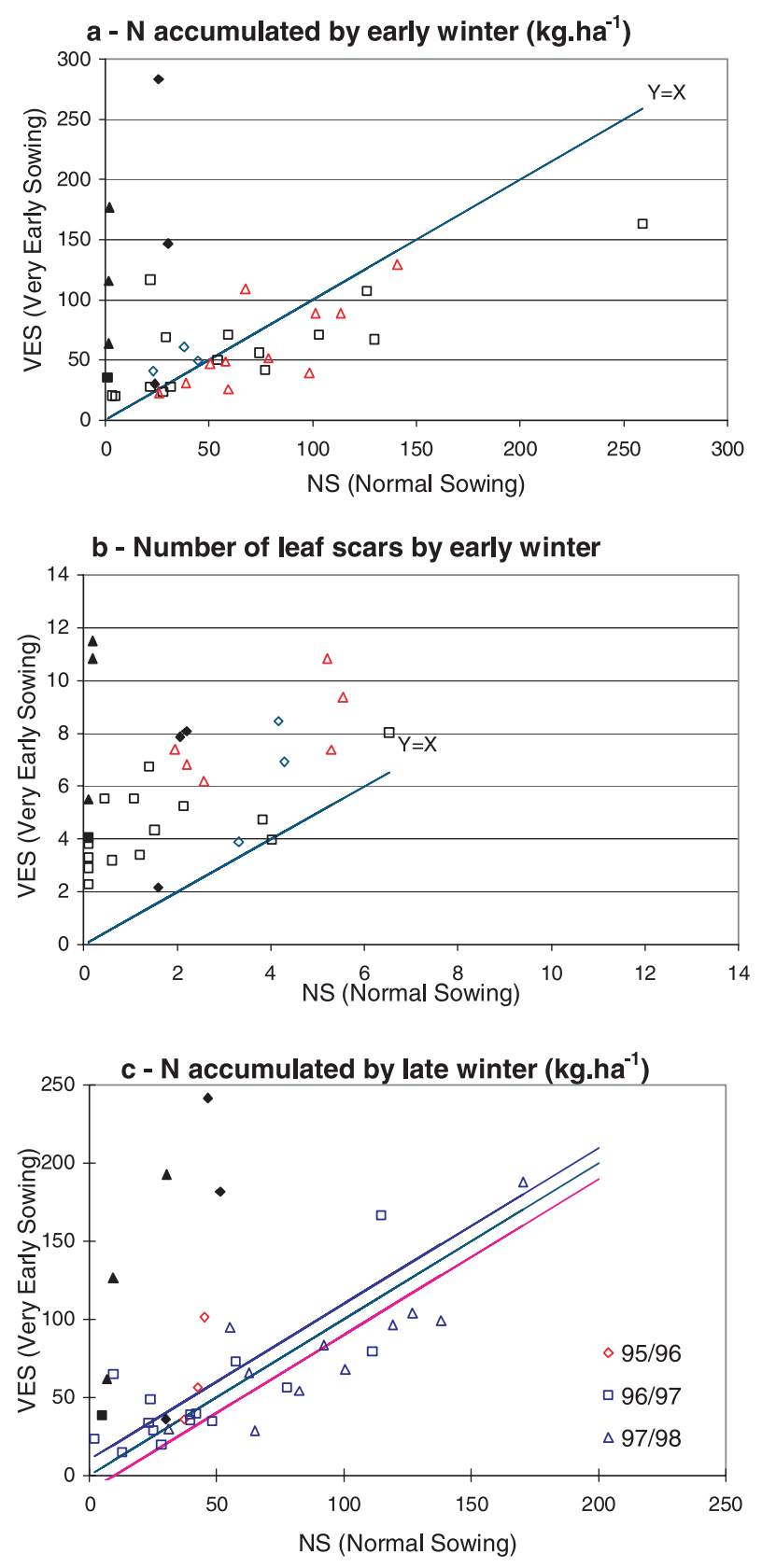

Figure 3. Very early sowing ( $\mathrm{Y}$-axis) compared with normal sowing (X-axis): nitrogen accumulated in shoots and roots in early winter (a) $\left(\mathrm{kg} \cdot \mathrm{ha}^{-1}\right)$, number of leaf scars in early winter (b) and nitrogen accumulated in shoots and roots in late winter (c) $\left(\mathrm{kg} \cdot \mathrm{ha}^{-1}\right)$. Each symbol represents an experiment. Filled symbols: late-emerged NS crops.

treatments was $27 \mathrm{~kg} \cdot \mathrm{ha}^{-1}$ in favour of NS, with very little spread (standard deviation $8 \mathrm{~kg} \cdot \mathrm{ha}^{-1}$ ). Conversely, the VES stand accumulated at least $10 \mathrm{~kg} \cdot \mathrm{ha}^{-1}$ more than the NS stand in 16 trials, with a mean of $62 \mathrm{~kg} \cdot \mathrm{ha}^{-1}$, but the amount of nitrogen accumulated was highly variable (standard deviation $57 \mathrm{~kg} \cdot \mathrm{ha}^{-1}$ ). Most of the late-emerged NS crops belong to this last group. Nitrogen fertiliser application rates were a mean of
$20 \mathrm{~kg} \cdot \mathrm{ha}^{-1}$ lower for VES plots than for NS plots. In four trials, the difference in nitrogen fertiliser application rates between VES and NS plots was over $100 \mathrm{~kg} \cdot \mathrm{ha}^{-1}$.

\subsubsection{Mineral nitrogen in the soil; estimation of nitrate leaching}

In VES plots, the amounts of soil mineral nitrogen $\left(\mathrm{NO}_{3}{ }^{-}\right.$ and $\mathrm{NH}_{4}{ }^{+}$) measured were low in early winter (Fig. 4a): under $40 \mathrm{~kg} \cdot \mathrm{ha}^{-1}$ over a depth of $90 \mathrm{~cm}$ in 33 of 36 trials and of the order of $50 \mathrm{~kg} \cdot \mathrm{ha}^{-1}$ for the remaining three trials. The same was true for $70 \%$ of the NS plots: good crop establishment, strong growth and strong nitrogen absorption in autumn resulted in low levels of residual nitrogen in the soil in these trials in early winter. However, several NS plots, particularly those in which the crop emerged late, contained very large amounts of mineral nitrogen, as much as $380 \mathrm{~kg} \cdot \mathrm{ha}^{-1}$. In six trials $(95.3 ; 96.9 ; 97.13 ; 95.2 ; 97.12$ and 96.6), much more mineral nitrogen was present in the soil in NS than in VES plots (100 to $300 \mathrm{~kg} \cdot \mathrm{ha}^{-1}$ more).

To validate the leaching function of the CERES rape model [13], we calculated, in 13 trials, the amount of mineral nitrogen in the soil at the end of winter, using the mineral nitrogen at the beginning of winter over $90 \mathrm{~cm}$ depth as an input. The comparison between the measured and simulated amounts of nitrogen at the end of winter was quite satisfactory (RMSEP = $\left.16.4 \mathrm{~kg} \cdot \mathrm{ha}^{-1}\right)$. The amount of nitrogen leached below the depth of $90 \mathrm{~cm}$ over winter was then calculated by simulation for each trial. The estimated amounts of nitrogen leached were larger for NS plots than for VES plots (Fig. 4b). On VES plots, no more than $30 \mathrm{~kg} \cdot \mathrm{ha}^{-1}$ was leached, whereas some of the NS plots lost more than $100 \mathrm{~kg} \cdot \mathrm{ha}^{-1}$ nitrogen by leaching, particularly if emergence was late and/or occurred after manure spreading. Slightly more water percolated below the depth of $90 \mathrm{~cm}$, as calculated using the CERES-Rape model, for NS than for VES plots (0 to $10 \%$ higher) (data not shown). The calculated concentration of nitrate in the water that percolated below the depth of $90 \mathrm{~cm}$ over the winter (Fig. 4c) was generally reduced by the VES crop management system. With VES, nitrate concentration exceeded the norm for drinking water of $50 \mathrm{mg} \cdot \mathrm{NO}_{3}{ }^{-} \cdot$ litre $^{-1}$ in only one trial (95.4); this trial was also the only one in which the VES crop did not emerge until September because of a lack of rain after sowing. With NS, nitrate concentrations varied considerably, from 1 to $325 \mathrm{mg} \cdot$ litre $^{-1}$, with late emergence having a strong negative effect. The six NS trials that differed from the others in having very high levels of mineral nitrogen in the soil in early winter (more than $100 \mathrm{~kg} \cdot \mathrm{ha}^{-1}$ ) produced very high levels of nitrogen leaching and very high concentrations of nitrate in the percolated water (more than $150 \mathrm{mg} \cdot$ litre $^{-1}$ ). In four of these six trials, organic manure or mineral fertiliser was applied before sowing (95.3; $96.9 ; 97.13$ and 96.6) and in five of these six trials, emergence was late $(95.3 ; 96.9 ; 97.13 ; 95.2$ and 97.12).

\subsection{Pest control}

VES made it possible to reduce the use of pesticides against slugs (Tab. III). However, contrary to the decision rules, several farmers applied slug pellets as a preventive measure with VES, especially in the second year, as they did not want to risk 

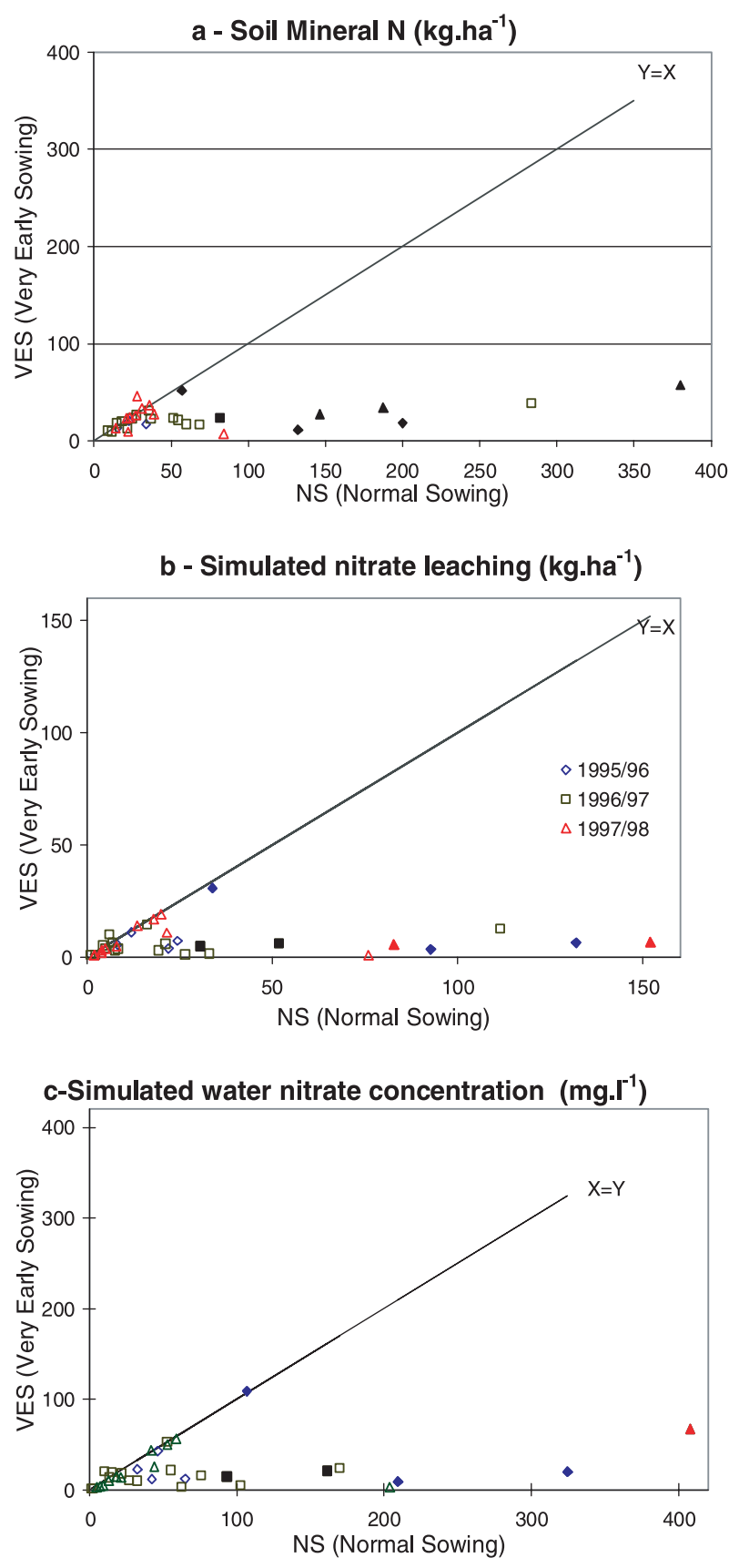

Figure 4. Very early sowing (Y-axis) compared with normal sowing (X-axis): soil mineral $\mathrm{N}\left(\mathrm{NO}_{3}{ }^{-}+\mathrm{NH}_{4}{ }^{+}, 0-90 \mathrm{~cm}\right)$ measured in early winter $\left(\mathrm{kg} \cdot \mathrm{ha}^{-1}\right)(\mathrm{a})$, nitrate leaching during winter simulated with CERES model $\left(\mathrm{kg} \cdot \mathrm{ha}^{-1}\right)(\mathrm{b})$, water nitrate concentration during winter simulated with CERES model $\left(\mathrm{mg} \cdot \mathrm{l}^{-1}\right)(\mathrm{c})$. Filled symbols: late-emerged NS crops.

damage to their crop. The weather was very favourable for slug activity in the first year [17], especially after emergence of the NS crops. Despite preventive and curative pesticide treatments, two of the seven NS plots had to be re-sown; in contrast, damage (plants eaten by slugs) was slight with VES. No damage was observed in years 2 and 3 .
Table III. Number of plots with at least one preventive or curative application of molluscicide. Number of plots with re-sowing of rapeseed after the plants were eaten through by slugs.

\begin{tabular}{lcccccc}
\cline { 2 - 7 } & \multicolumn{2}{c}{$1995 / 96$} & \multicolumn{2}{c}{$1996 / 97$} & \multicolumn{2}{c}{$1997 / 98$} \\
\cline { 2 - 7 } & \multicolumn{2}{c}{$\mathrm{N}=7$} & \multicolumn{2}{c}{$\mathrm{N}=16$} & \multicolumn{2}{c}{$\mathrm{N}=13$} \\
\cline { 2 - 7 } & $\mathrm{NS}$ & $\mathrm{VES}$ & $\mathrm{NS}$ & $\mathrm{VES}$ & $\mathrm{NS}$ & $\mathrm{VES}$ \\
\hline Preventive & 1 & 0 & 8 & 6 & 4 & 0 \\
Curative & 5 & 2 & 1 & 1 & 0 & 0 \\
Re-sowing of the plot & 2 & 0 & 0 & 0 & 0 & 0 \\
\hline
\end{tabular}

$(\mathrm{N}=$ number of plots per year $)$

Insecticides were sprayed when the pest population exceeded the decision rule thresholds, in both VES and NS crop management systems. However, contrary to our initial hypotheses, there was little difference between the two sowing dates as regards the number of autumn treatments: $+19 \%$ more insecticide in autumn with VES or a mean of 1.06 insecticide treatments per field versus 0.89 with NS. The extra insecticide was applied mainly to deal with turnip sawfly and aphids. No significant insect damage was observed by early winter (damage score $<3$ ) with either VES or NS.

Stem canker damage was scored when taking samples at stage G4, shortly before harvest. In most trials, damage scores were similar for the two crop management systems, but in 10 of the 13 cases in which there was a difference, the VES crop was affected more severely than the NS crop. In two trials (96.11 and 97.3), stem canker damage scores exceeded 5 for VES crops but reached a maximum of only 3.2 for the NS crops in the same trials.

The major difference between the crop management systems in terms of weeding was the necessity with VES to intensify measures against volunteers of the preceding cereal crop, consistent with the shorter period between harvest and sowing. In all trials, weed control was effective against all except some summer-germinating species (Amaranthus reflexus L. and Chenopodium album L.), which emerged mostly in VES plots. These species were able to complete their cycle, and therefore to produce seeds, before they were killed by winter frost. Lastly, on two NS plots sown late (95.2 and 95.3), the weeding programme was simplified (post-emergence herbicide was not possible before winter) and the rape was infested with broadleaved weeds, mostly chickweed (Stellaria media L.).

\subsection{Yield, gross margins and soil mineral nitrogen after harvest}

The spring network consisted of 26 trials (versus 36 trials in the autumn network). The yield obtained with NS was more than $10 \%$ higher than that with VES in five cases and was similar (difference VES-NS lower than 10\%) in 13 cases (Fig. 5). However, the yield obtained with NS crops was $10 \%$ below that of VES crops in 8 cases, including all cases in which the NS crop emerged late. Due to the recording of a few very low yields, the range of yields for NS crops $\left(1.1\right.$ to $4.1 \mathrm{Mg} \cdot \mathrm{ha}^{-1}$ ) was wider than that for VES crops $\left(2.3\right.$ to $\left.4.4 \mathrm{Mg} \cdot \mathrm{ha}^{-1}\right)$. By contrast, some very high yields, close to $4.0 \mathrm{t} \cdot \mathrm{ha}^{-1}$, were achieved with both sowing dates over the three years of the 


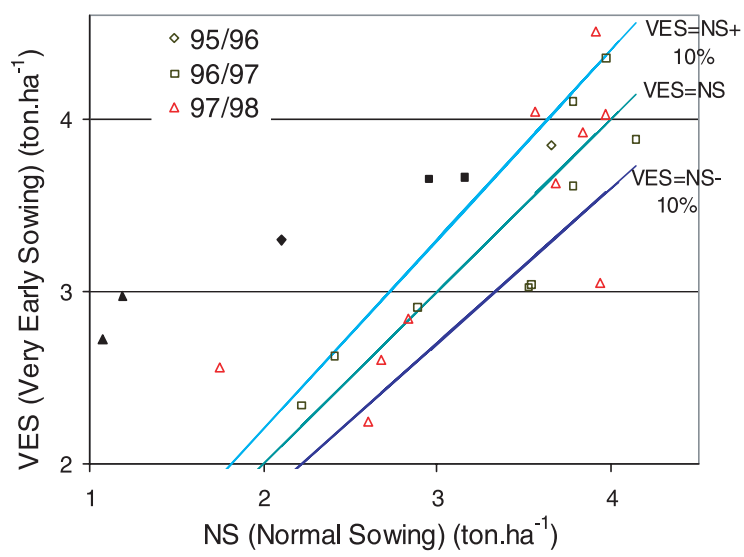

Figure 5. Yield (ton $\cdot \mathrm{ha}^{-1}$ ) of very early sowing (Y-axis) compared with yield of normal sowing (X-axis). Filled symbols: late-emerged NS crops.

study. The oil and protein levels of the seeds obtained with the two crop management systems were very similar in a given trial (data not shown) and varied widely over the trials (15 to $24 \%$ protein, 38 to $52 \%$ oil).

There was little difference in cost between NS and VES. The only differences in operating costs were those for molluscicide (costs less for VES in all cases) and nitrogen fertiliser (costs generally less for VES). Consequently, differences in gross margin were mainly due to differences in yield $\left(\mathrm{r}^{2}=\right.$ $0.86, \mathrm{n}=26$ ).

The difference between VES and NS plots in terms of residual mineral nitrogen in the soil at the G4 stage was less than $10 \mathrm{~kg} \cdot \mathrm{ha}^{-1}$ in half the trials. For the other trials, the differences in residual mineral nitrogen (DRMN, $\mathrm{kg} \cdot \mathrm{ha}^{-1}$ ) at G4 were partly accounted for by differences in yield (DY, $\mathrm{t} \cdot \mathrm{ha}^{-1}$ ) $\left(\mathrm{DRMN}=-28.6 \mathrm{DY}-4.0 \mathrm{R}^{2}=0.40, \mathrm{n}=17, P<0.05\right)$. In most trials, less than $40 \mathrm{~kg} \cdot \mathrm{ha}^{-1}$ of residual mineral nitrogen was left in the soil (data not shown), showing that the nitrogen supply was generally not excessive.

\section{DISCUSSION}

\subsection{Is early-sown rape an efficient nitrate trap?}

The amount of nitrogen available to the rape in autumn in the various trials, estimated from total nitrogen accumulated in the plants and mineral nitrogen in the soil before winter drainage, varied greatly between trials, from 50 to $380 \mathrm{~kg} \cdot \mathrm{ha}^{-1}$. As the amount of nitrogen lost through leaf-fall is not known, this partial evaluation underestimates the available nitrogen but does give an indication of the range covered. Very large quantities of nitrogen were available in very deep soils and in fields to which nitrogen was added in the form of organic manure. By contrast, all the rendzinas (most of the trials in the east) had low levels of available nitrogen $\left(50 \mathrm{~kg}\right.$ to $\left.70 \mathrm{~kg} \cdot \mathrm{ha}^{-1}\right)$. VES crops systematically absorbed almost all the nitrogen present in the soil in autumn, and accumulated up to $280 \mathrm{~kg} \cdot \mathrm{ha}^{-1}$ of nitrogen. This demonstrates very clearly the high nitrogentrapping capacities of early-sown rape. In one trial, similar results were obtained with NS (260 kg accumulated), but this was dependent on several conditions: relatively early sowing (end of August), and moisture and temperature conditions favourable for rapid emergence and strong growth in autumn. The achievement of good results is more subject to chance with NS than with VES. Several NS crops, particularly those that emerged late, showed poor to moderate growth although a large amount of residual nitrogen was present in the soil in early winter. Thus, despite favourable temperature conditions in the autumn during the 3 years, delaying emergence by two or three weeks was sufficient to limit aerial plant growth and to create a high risk of leaching [36]. VES ensured the complete removal of nitrogen from the soil before winter percolation and was therefore of environmental value.

The measurement of mineral nitrogen in the soil in early winter and the concentration of $\mathrm{NO}_{3}{ }^{-}$in percolation water, simulated by CERES-Rape, clearly showed that very early sowing was useful for preventing nitrate loss, especially after the spreading of organic manure. It is therefore worth considering the use of a rape crop sown early during summer to mop up excess summer nitrate, especially in livestock farming regions.

According to the data for the accumulation of nitrogen in the plants and of mineral nitrogen in the soil in early winter, it is possible to distinguish 3 groups of crops (Fig. 6):

- Low accumulation in both plant and soil: nitrogen accumulation in the plants is limited by soil supply; the risk of nitrate pollution of groundwater is low, whatever the sowing date;

- High levels of accumulated nitrogen in the plant, and low nitrate levels in the soil. Despite the large amounts of nitrogen supplied, the risk of leaching is low; this group contained mostly VES crops;

- Low levels of accumulated nitrogen in the plant, and high nitrate levels in the soil. The soil supply is high, the trapping capacity of the crop low, and the risk of nitrate pollution is high. This group contained only NS crops.

VES was of limited advantage in terms of reducing nitrogen fertiliser applications, especially as VES crops lost more leaves than NS crops, as indicated by the scar count. For VES crops in autumn, there was no correlation between crop N status and leaf fall. These data are consistent with those of Dejoux [6], who showed that leaf fall in autumn was linked to degree-day accumulation. Leaf-dropping by VES crops, whether in autumn or winter, may account for the loss of large amounts of nitrogen (between $30 \mathrm{~kg}$ and $200 \mathrm{~kg} \cdot \mathrm{ha}^{-1}$, measured at an experimental station by Dejoux [6]). However, the decomposition of these dead leaves may increase the amount of nitrogen available to the rape after winter [8].

\subsection{Early-sown rape and pest avoidance}

Pest avoidance occurs when there is a time-lag between the period in which the crop is vulnerable and the period favourable to the activity of pests and disease organisms [12]. With VES, primary stem canker infections of the rape crop in the early stages of growth were avoided. The period of ascospore dispersal, recorded in all three trial regions, occurred, as expected [27], quite late (mid-September-October), when the VES plants had at least three or four leaves and were no longer susceptible to primary stem canker infection [26]. However, stem canker 


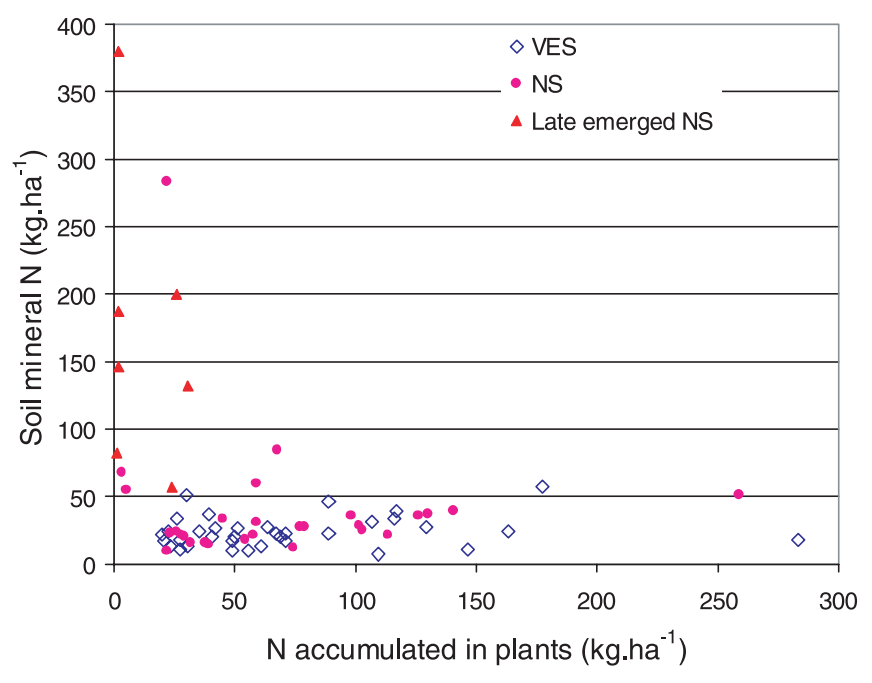

Figure 6. Soil mineral $\mathrm{N}\left(\mathrm{NO}_{3}{ }^{-}+\mathrm{NH}_{4}{ }^{+}, 0-90 \mathrm{~cm}\right)$ measured by early winter $\left(\mathrm{kg} \cdot \mathrm{ha}^{-1}\right)(\mathrm{Y}$-axis) related to nitrogen accumulated in shoots and roots by early winter $\left(\mathrm{kg} \cdot \mathrm{ha}^{-1}\right)$ (X-axis).

damage scores recorded shortly before harvest tended to be higher with VES than with NS. It seems likely that the large leaf scars observed in VES stands provided a major gateway for late secondary infection by pycnidiospores [27].

VES seemed to result in avoidance of the main species of slugs (Deroceras reticulatum Müller and Arion distinctus Mabille), especially in autumn 1995 (see Tab. III). Slug injury between germination and the two-true-leaves stage may result in severing of the hypocotyl and destruction of the plant [15]. Higher temperatures, facilitating faster growth, rendered the phase of vulnerability, expressed in days, shorter with VES than with NS. Furthermore, slug activity depends on moisture conditions in the topsoil and atmosphere [38] and high temperatures are unfavourable for slug activity [16]. However, NS crops were not systematically damaged by slugs: the weather conditions in September were unfavourable for slugs in years 2 and 3. Given the considerable moisture deficit in July and August in France, early sowings (early August) are likely to result in the avoidance of slug damage in many cases. The reduction in the use of molluscicides facilitated by early sowing is of great value for environmental protection because the active ingredients of molluscicides are considered to be highly polluting [35].

Early sowing led to a slight increase in the use of herbicides to deal with volunteer cereals in particular, and in the use of insecticides. Greater knowledge concerning the effect of weeds and pests on early-sown rape is required if we are to adapt the decision rules to the new crop management system. In this study, we did not try to eliminate pre-emergence herbicide applications; this could probably be done in certain fields in which the crop grows strongly enough to be very competitive against weeds [7].

\subsection{Yield-limiting factors and economic performance of early-sown rape}

Contrary to our initial expectations, problems with emergence and frost damage did not seem to limit production with the VES system. According to a synoptic report on agronomic problems in rape crops throughout Europe [22], poor crop establishment (late emergence, insufficient plant density, etc.) is a common problem. The results obtained for the VES crop management system in our network seem to be satisfactory in this respect because the targets for emergence dates were more frequently achieved for VES crops than for NS crops. The heavy rains immediately preceding emergence were sufficient for the establishment of an adequate moisture stock for the initial growth of the crop. In addition, summer temperatures were favourable for more rapid growth in VES crops, which may have facilitated development of the root system [32]: in two trials, we observed at the "four true leaves" stage (20 days after sowing) that the taproot had reached a depth of $30 \mathrm{~cm}$. We did not need to re-sow in the event of poor emergence in VES management because the available information [25] indicated that plant densities were high enough for the achievement of target yields.

Even at low temperatures, we observed no major destruction of VES crops during winter (maximum loss of $10 \%$ of the plants). The stands with the highest growth rates did not incur frost damage, even if the stem elongated by $5 \mathrm{~cm}$ to $15 \mathrm{~cm}$ in the autumn, a frost-susceptibility factor according to Torsell [34] and Topinka et al. [33]. Our network did not include combinations of rape crops that had accumulated more than $120 \mathrm{~kg}$ $\mathrm{N} \cdot \mathrm{ha}^{-1}$ and had experienced minimum winter temperatures below $-8^{\circ} \mathrm{C}$, as none of the trials with a very high nitrogen supply were in the coldest region. Dejoux [6], however, showed that winter frost susceptibility $\left(-14^{\circ} \mathrm{C}\right)$ was similar for VES and NS crops with high $\mathrm{N}$ uptake in the autumn, even if greater stem elongation was observed with VES.

Table IV summarises the mean yields and gross margins of NS and VES crops according to the main limiting factors observed in the trials.

For five of the 26 trials, yields and gross margins were higher for the NS crops. In the two trials (class B) in which the VES crop scored more than 5 for stem canker and the NS crop scored less than 3.2, the yield of the NS crop was more than $10 \%$ greater than that of the VES crop. The three VES stands in class $\mathrm{C}$ accumulated little nitrogen in early winter, between 20 and $40 \mathrm{~kg} \cdot \mathrm{ha}^{-1}$, whereas the NS stand accumulated 30 to $60 \mathrm{~kg} \cdot \mathrm{ha}^{-1}$ more nitrogen before winter. Consistent with the work of Colnenne [5], the very low levels of $\mathrm{N}$ absorption of VES stands before winter led to a deficit in crop production, although there were no weeds in spring and no particular pest or disease problems in these trials. Dejoux [6], in experiments with low $\mathrm{N}$ availability, also observed higher levels of nitrogen accumulation before winter in rape crops sown on the usual date than in crops sown early. He attributed this difference to a complex interaction between nitrogen and water. Early sowing was carried out on land on which the preceding crop left very low nitrogen levels; the crop therefore suffered early severe nitrogen deficiency, which directly affected aerial growth. However, by the normal sowing date, summer mineralisation had enriched the soil in nitrogen, especially as the topsoil had not been dried out by a standing crop, as was the case with VES. Thus, nitrogen deficiency occurred much later in NS crops.

In six trials (class A), the NS crop was sown after September 15 and emerged after September 25. In five of these six 
Table IV. Mean yield and gross margin of the crops, according to trial type.

\begin{tabular}{|c|c|c|c|c|c|c|c|}
\hline & $\begin{array}{l}\text { Number of trials (and } \\
\text { identification number of } \\
\text { the trials) }\end{array}$ & $\begin{array}{c}\text { Mean NS } \\
\text { yield }\end{array}$ & $\begin{array}{l}\text { Mean VES } \\
\text { yield }\end{array}$ & $\begin{array}{c}\text { Difference in } \\
\text { yield } \\
\text { (VES-NS) }\end{array}$ & $\begin{array}{l}\text { Mean NS gross } \\
\text { margin }\end{array}$ & $\begin{array}{l}\text { Mean VES } \\
\text { gross margin }\end{array}$ & $\begin{array}{l}\text { Difference in } \\
\text { gross margin } \\
(\mathrm{VES}-\mathrm{NS})\end{array}$ \\
\hline Class & & $\mathrm{t} \cdot \mathrm{ha}^{-1}$ & $\mathrm{t} \cdot \mathrm{ha}^{-1}$ & $\mathrm{t} \cdot \mathrm{ha}^{-1}$ & $€ \cdot \mathrm{ha}^{-1}$ & $€ \cdot \mathrm{ha}^{-1}$ & $€ \cdot \mathrm{ha}^{-1}$ \\
\hline A (late-emerged NS) & $\begin{array}{c}6 \\
(95.3 ; 96.8 ; 96.9 ; 97.12 ; 97.13 \\
96.7)\end{array}$ & 2.37 & 3.31 & 0.94 & 225 & 460 & 234.6 \\
\hline B (Stem canker in VES) & $\begin{array}{c}2 \\
(96.11 ; 97.3)\end{array}$ & 3.79 & 3.33 & -0.45 & 526 & 465 & -61.8 \\
\hline C (low New** in VES) & $\begin{array}{c}3 \\
(96.3 ; 97.9 ; 97.11)\end{array}$ & 3.35 & 2.80 & -0.55 & 502 & 361 & -140.5 \\
\hline $\begin{array}{l}\mathrm{D} \text { (no differences in } \\
\text { limiting factors in both } \\
\text { VES and NS) }\end{array}$ & $\begin{array}{c}15 \\
(96.1 ; 96.2 ; 97.2 ; 97.8 ; 95.1 ; \\
96.6 ; 96.13 ; 96.14 ; 96.15 ; 97.1 \\
97.4 ; 97.6 ; 97.5 ; 97.7 ; 97.10)\end{array}$ & 3.28 & 3.48 & 0.19 & 461 & 500 & 38.2 \\
\hline Total $*$ & $26^{*}$ & & & & & & \\
\hline Mean & & 3.12 & 3.35 & 0.23 & 416 & 472 & 55.1 \\
\hline
\end{tabular}

cases, yield (and gross margin) was higher with VES. The consequences of the late establishment of these stands were weak autumn growth [20], low accumulation of nitrogen before winter (less than $10 \mathrm{~kg} \cdot \mathrm{ha}^{-1}$ ), weed infestation in autumn (96.8, 96.9 and 95.3), which was not dealt with in spring (95.3, chickweed) and, in some cases, soil compaction (96.8 and 96.9) and waterlogging (95.3). Winter rape is known to be highly sensitive to soil compaction and waterlogging $[1,31]$.

For the last 15 trials (class D), we identified no difference in limiting factors between NS and VES crops: there were no problems of late sowing, stem canker or weeds, and the amounts of nitrogen accumulated in the rape stand before winter were low or high, but in all cases similar for NS and VES.

\section{CONCLUSION}

We evaluated an innovative oilseed rape crop management system under a large range of biophysical conditions. Evaluation of such technical innovations goes beyond classical experiments in which one or two management factors are changed under the ceteris paribus assumption. Our approach is rooted in the evaluation of decision rules, based on agronomic knowledge, that are relevant for all production locations.

The use of on-farm experiments made it possible to explore a large diversity of "soil-climate-cropping history" conditions, ensuring the reliability of our results. However, experiments on crop management systems involving a large number of plots and farmers are not without disadvantages. For example, several deviations from the decision rules were observed in the network. However, these deviations were few in number and were taken into account in the analysis of the results. A more tricky problem was the large size of experimental plots required for the use of agricultural machinery, which made it necessary to simplify each experimental situation and to carry out each trial without replicates. We tried to maximise precision by setting up the trials only after carefully checking that the soil was homogeneous. However, it was impossible to carry out statis- tical comparisons at each site. In such a network, demonstrations are based on the coherence of the results obtained over the whole set of trials [24], as for the analysis of the results of on-farm surveys [9].

This experimental assessment of a new crop management system for oilseed rape identified several advantages and disadvantages:

- Absorption of almost all the mineral nitrogen present in the soil in autumn, resulting in a nitrate concentration of the percolated water below $50 \mathrm{mg} \cdot \mathrm{1}^{-1}$;

- Fewer molluscicide treatments, even in years of heavy slug infestation;

- Yield and gross margin similar to or higher than those for crops sown at the usual date, unless little nitrogen is available in the soil in autumn [class C] or the risk of stem canker is high [class B]. In particular, early-sown rape seems to establish well, and in cases of poor emergence, it is possible to re-sow at the usual sowing date, with no major increase in total costs.

Very early sowings are therefore of particular value in situations in which high levels of nitrogen are present in the soil in autumn (after organic manure spreading, or low recovery of the fertiliser of the previous crop) and on soils that drain slowly, in which the farmer may otherwise be obliged to sow late [2]. However, if little nitrogen is available in autumn, very early sowing seems to create a risk of yield losses. In such cases, the value of additional nitrogen application early in autumn should be evaluated. A more thorough knowledge of the effects of nitrogen deficiency is required to define limitations for the use of the very early sowing crop management system.

Acknowledgements: We would like to thank all of the farmers who were involved in the trials, the CETIOM engineers who ran the crop management systems (D. Chollet, J.L. Lespinas, J.P. Palleau and P. Simonin), and the engineers and technicians of the extension services (Chambres d'Agriculture 5552-26-86-79-17; CAVAC, Champagnes-Céréales and Agrotransfert PoitouCharentes). We thank the following people for technical support in monitoring of the trials: G. Grandeau, D. Wagner, O. Rosselet, J.F. Leblond, E. Fovart and the personnel of the experimental unit at Grignon, directed by J Troizier. This project was funded by INRA, CETIOM, SIDO and GIS AGRICE. 


\section{REFERENCES}

[1] Ashraf M., Mehmood S., Effects of waterlogging on growth and some physiological parameters of four Brassica species, Plant and Soil 121 (1990) 203-209.

[2] Boiffin J., Fabre J.C., Gautronneau Y., Sebillotte M., Les risques de mauvaise levée du colza d'hiver en terre battante. Analyse d'une expérimentation de longue durée en vue de leur prévision, Inf. Tech. CETIOM 73 (1981) 12-28.

[3] CETIOM, Guide de l'expérimentateur CETIOM, 1994.

[4] CETIOM, Colza d'hiver - Le contexte économique, les techniques culturales, les débouchés - Brochure annuelle, CETIOM, Paris, 1998.

[5] Colnenne C., Les besoins en azote du colza d'hiver : courbe critique de teneur en azote et effets de carences temporaires sur l'élaboration du rendement, 1999, Thèse de Doctorat, INA P-G, Paris, 201 p. + annexes.

[6] Dejoux J.F., Évaluation d'itinéraires techniques du colza d'hiver en semis très précoces. Analyse agronomique, conséquences environnementales et économiques, 1999, Thèse de doctorat, INA P-G, Paris, 244 p. + annexes.

[7] Dejoux J.F., Ferré F., Meynard J.M., Effects of sowing date and nitrogen availability on competitivity of rapeseed against weeds in order to develop new strategies of weeds control with reduction of herbicides use, 1999, in: New horizons for an old crop, Proc. of the 10th Int. Rapeseed Congress, GCIRC, Canberra-Australia, 26-29/ 09/99.

[8] Dejoux J.F., Recous S., Meynard J.M., Trinsoutrot I., Leterme P., The fate of nitrogen from winter-frozen rapeseed leaves: mineralization, fluxes to the environment and uptake by rapeseed crop in spring, Plant and Soil 218 (2000) 257-272.

[9] Doré T., Sebillotte M., Meynard J.M., A diagnosis method for assessing regional variations in crop yield, Agric. Syst. 54 (1997) 169-188.

[10] Driessen P.M., The water balance of soil, in: Van Keulen H., Wolf J. (Eds.), Modelling of agricultural production: weather, soils and crops, PUDOC, Wageningen, The Netherlands, 1986, pp. 76-116.

[11] Fleury A., Effet des dates de réalisation des opérations culturales sur l'élaboration du rendement des espèces annuelles, Bull. Tech. Inf. 412 (1986) 705-716.

[12] Frank T., Sown wildflower strips in arable land in relation to slug density and slug damage in rape and wheat, 1996, in: Slug and Snail Pests in Agriculture, British Crop Protection Council (BCPC), Kent, Canterbury, 24-26/09/96, pp. 289-296.

[13] Gabrielle B., Denoroy P., Gosse G., Justes E., Andersen M.N., Development and evaluation of a CERES-type model for winter oilseed rape, Field Crops Res. 57 (1998) 95-111.

[14] Gautronneau Y., Manichon H., Guide méthodologique du profil cultural, CEREF-GEARA, 1987.

[15] Glen D.M., Jones H., Fieldsend J.K., Damage to oilseed rape seedlings by the field slug Deroceras reticulatum in relation to glucosinolate concentration, Ann. Appl. Biol. 117 (1990) 197-207.

[16] Hommay G., Contribution à la biologie et à l'écologie des limaces (mollusques gastéropodes pulmonés) de grandes cultures, 1994 Thèse de Doctorat, Rennes I, 272 p. + annexes.

[17] Lagarde F., Bilan phytosanitaire 1996 colza, tournesol et soja. Le calme avant la tempête ? Phytoma 490 (1997) 40-41.

[18] Leterme P., Modélisation de la croissance et de la production des siliques chez le colza d'hiver ; application à l'interprétation de résultats de rendement, 1985, Thèse de Docteur-Ingénieur, INA PG, Paris, 112 p. + annexes.

[19] Lutman P.J.W., Bowerman P., Palmer G.M., Whytock G.P., Response of oilseed rape to interference from Stellaria media, Bull. GCIRC 13 (1997) 61-63.

[20] Mendham N.J., Shipway P.A., Scott R.K., The effects of delayed sowing and weather on growth, development and yield of winter oil-seed rape (Brassica napus), J. Agric. Sci. (Camb.) 96 (1981) 389-416.

[21] Merrien A., Pouzet A., Principaux facteurs limitant les rendements du colza d'hiver dans les conditions françaises, Physiologie et élaboration du rendement du colza d'hiver, CETIOM-INRA, Paris, 1988, pp. 16-19.

[22] Meynard J.M., Askew M.F., Bockey D., Ceccon P., Christen O., Debaeke P., Dejoux J.F., Evans E., Falisse A., Gonzalez P., Haldrup C., Nilsson B., Reau R., Eléments de réflexion sur les priorités de recherche concernant les systèmes de culture dans l'Union européenne, OCL 5 (1998) 82-85.

[23] Meynard J.M., Boiffin J., Caneill J., Sebillotte M., Élaboration du rendement et fertilisation azotée du blé d'hiver en Champagne Crayeuse. II. Types de réponse à la fumure azotée et application de la méthode du bilan prévisionnel, Agronomie 1 (1981) 795-806.

[24] Meynard J.M., Reau R., Robert D., Saulas P., Évaluation expérimentale des itinéraires techniques, 1996, in: Expérimenter sur les conduites des cultures : un nouveau savoir-faire au service d'une agriculture en mutation, DERF-ACTA, comité potentialités, Paris, France, 10/01/96, pp. 63-72.

[25] Palleau J.P., Bilan de 10 ans d'expérience à l'observatoire colza, CETIOM, Oléoscope Numéro spécial n 12, Paris, 1993.

[26] Penaud A., Phoma du colza : à la recherche d'un bon indicateur pour traiter, Oléoscope 35 (1996) 16-17.

[27] Pérès A., Poisson B., Maisonneuve C., Phoma du colza : comment le champignon progresse dans le plante ? Oléoscope 35 (1996) 10 12 .

[28] Pouzet A., Agronomy, in: Kimber D.S., McGregor D.I. (Eds.), Production and Utilization of Brassica Oilseeds, CAB International, Oxford, 1995, pp. 65-92.

[29] Reau R., Jung L., Wagner D., Les bases de la fertilisation azotée prévisionnelle, in: Le Page R., Reau R. (Eds.), Fertilisation azotée du colza d'hiver, Oléoscope numéro spécial $n^{\circ}$ 20, CETIOM, Paris, 1997, pp. 29-37.

[30] Reau R., Meynard J.M., Robert D., Gitton C., Des essais factoriels aux essais conduites de culture, 1996, in: Expérimenter sur les conduites des cultures : un nouveau savoir-faire au service d'une agriculture en mutation, DERF-ACTA, Comité Potentialités, Paris, France, 10/01/96, pp. 52-62.

[31] Silvestre J., Morard P., Winter oilseed rape behaviour under temporary hypoxic conditions, C.R. Acad. Agric. Fr. 80 (1994) 145156.

[32] Thorup Christensen K., Root development of nitrogen catch crops and of a succeeding crop of broccoli, Acta Agric. Scand. Soil Plant Sci. 43 (1993) 58-64.

[33] Topinka A.K.C., Downey R.K., Rakow G.F.W., Effect of agronomic practices on the overwintering of winter Canola in southern Alberta, 1991, in: Rapeseed in a changing world, Proceedings of the 8th International Rapeseed Congress, Ed. McGregor D.I., GCIRC, Saskatoon, Canada, 9-11 July 1991, pp. 665-670.

[34] Torsell B., Hardiness and Survival of Winter Rape and Winter Turnip Rape, Department of Plant Husbandry (Crop Production), 1959.

[35] van der Werf H.M.G., Assessing the impact of pesticides on the environment, Agric. Ecosyst. Environ. 60 (1996) 81-96.

[36] Vos J., van der Putten P.E.L., Field observations on nitrogen catch crops. I. Potential and actual growth and nitrogen accumulation in relation to sowing date and crop species, Plant and Soil 195 (1997) 299-309.

[37] Williams I.H., Darby R.J., Leach J.E., Rawlinson C.J., An analysis of factors affecting yield in winter rape, 1991, in: Rapeseed in a changing world, Proceedings of the Eighth International Rapeseed Congress, Ed. McGregor D.I., GCIRC, Saskatoon, Canada, 9-11 July 1991, pp. 612-616.

[38] Young A.G., Port G.R., Green D.B., Development of a forecast of slug activity: validation of models to predict slug activity from meteorological conditions, Crop Prot. 12 (1993) 232-236. 